\title{
Seasonal and diel movements of giant trevally Caranx ignobilis at remote Hawaiian atolls: implications for the design of Marine Protected Areas
}

\author{
Carl G. Meyer ${ }^{1, *}$, Kim N. Holland ${ }^{1}$, Yannis P. Papastamatiou ${ }^{2}$ \\ ${ }^{1}$ Hawaii Institute of Marine Biology, University of Hawaii at Manoa, PO Box 1346, Coconut Island, Kaneohe, Hawaii 96744, USA \\ ${ }^{2}$ Department of Zoology, Edmonson Hall, University of Hawaii at Manoa, Honolulu, Hawaii 98822, USA
}

\begin{abstract}
We need to understand the long-term movement patterns of coral reef top predators in order to design marine protected areas that will provide these animals with effective, long-term protection. We used acoustic telemetry to quantify the movements of giant trevally, a large coral reef top predator, at 5 atolls in the Northwestern Hawaiian Islands Marine National Monument. We did not observe any inter-atoll movements but found that giant trevally were attached to core activity areas from which they made periodic atoll-wide excursions of up to $29 \mathrm{~km}$. Within the core areas, the tagged fish exhibited diel habitat shifts. We identified Rapture Reef at French Frigate Shoals (FFS) atoll as a spawning site, where giant trevally form seasonal mating aggregations. Giant trevally that use Rapture Reef as their core daytime area live there year-round, whereas those that occupy other areas of FFS migrate to Rapture Reef in the summertime during specific phases of the moon. Although giant trevally were wide-ranging and would require large marine protected areas (e.g. entire atolls or islands) to protect their entire range, core activity areas and spawning sites for giant trevally could be contained within relatively small marine protected areas. Identification of spawning sites could assist in the establishment of focused marine protected areas that, while quite small in size, could have significant impact in preserving the spawning biomass of this species. Very large marine protected areas are not feasible in most heavily populated areas, hence effective alternative management strategies must be found for this fishery-targeted, wide-ranging top predator. We suggest using a combination of relatively small marine protected areas, to protect core activity areas and spawning sites for giant trevally, and conventional measures such as minimum size or 'slot' limits to further safeguard spawning stocks.
\end{abstract}

KEY WORDS: Top predator $\cdot$ Marine Protected Areas $\cdot$ MPAs $\cdot$ Spawning migrations $\cdot$ Diel migrations $\cdot$ Acoustic monitoring $\cdot$ Giant trevally $\cdot$ Caranx ignobilis $\cdot$ Carangidae

\section{INTRODUCTION}

We need to know how far coral reef top predators range over months or years in order to design marine protected areas (MPAs) that contain appropriate habitat types and are large enough to provide effective, long-term protection for these animals. Despite this basic design requirement and the burgeoning popularity of MPAs as coral reef management tools, empirical data quantifying long-term movement patterns and space requirements of coral reef fishes remain scarce (Roberts \& Polunin 1993, Kramer \& Chapman 1999, Nowlis \& Roberts 1999, Sadovy et al. 2003, Gerber et al. 2005, Meyer \& Holland 2005). This is of particular concern given that most existing MPAs are relatively small $\left(74 \%<10 \mathrm{~km}^{2}\right.$, Halpern 2003) yet coral reef top predators are potentially wide-ranging (Sadovy et al. 2003, Meyer \& Honebrink 2005, Lowe et al. 2006).

The giant trevally Caranx ignobilis is a large top predator (up to $170 \mathrm{~cm}$ total length; $80 \mathrm{~kg}$ ) found on 
coral reefs across the Indo-Pacific region, where it is extensively targeted by fishers (Williams 1958, Bagnis et al. 1972, Berry et al. 1981, Randall 1996, Meyer et al. 2001). A previous, small-scale acoustic monitoring study (3 fish) at Midway atoll (Northwest Hawaiian Islands) found that adult giant trevally range back and forth up to $9 \mathrm{~km}$, and 1 fish showed evidence of diel and seasonal shifts in habitat use (Lowe et al. 2006). In the Northwest Hawaiian Islands, giant trevally spawn during the summer months (Sudekum et al. 1991). Elsewhere in the Pacific they are known to aggregate at traditional summer spawning locations during the full moon, but there is no information on how far they travel to participate in these aggregations (Williams 1965, Bagnis et al. 1972, von Westerhagen 1974, Johannes 1978, 1981).

Although giant trevally numbers have been depleted in populated areas (Shomura 1987) they are still abundant throughout the remote atolls and reefs of the Northwestern Hawaiian Islands Marine National Monument (NWHI-MNM) (Sudekum et al. 1991, Friedlander \& DeMartini 2002, DeMartini et al. 2005). Therefore the NWHI-MNM provides an ideal opportunity to quantify the patterns and scale of long-term movements by coral reef top predators in an unexploited environment, and to evaluate the minimum MPA size required for effective long-term protection of these large animals. We used acoustic monitoring to empirically quantify long-term movements of giant trevally in the NWHI-MNM and address 3 questions relevant to MPA design: (1) do giant trevally move across open ocean between atolls, (2) how extensive are their intra-atoll movements, and (3) do giant trevally exhibit predictable temporal (diel, lunar \& seasonal) movement patterns?

\section{MATERIALS AND METHODS}

Study site. The NWHI-MNM consists of a series of rocky pinnacles, atolls, reefs and submerged banks that extend $1930 \mathrm{~km}$ from Nihoa Rock to Kure Atoll, and encompass an area of $341360 \mathrm{~km}^{2}$ (Fig. 1). These sites are closed to fishing and are characterized by predator-dominated fish assemblages (Friedlander \& DeMartini 2002). We conducted our study at 5 atolls in the NWHI-MNM: French Frigate Shoals Atoll (FFS), Maro Reef (MAR), Pearl and Hermes Reef (PHR), Midway Atoll (MID) and Kure Atoll (KUR, Fig. 1). Four of these sites (KUR, MID, PHR, FFS) are classical atolls, with well defined barrier reefs and central lagoons, whereas Maro Reef is an open atoll with a reticulated reef system (Table 1). These atolls range in area from 68 to $469 \mathrm{~km}^{2}$, and in length (longest axis) from 10 to 36 km (Table 1). Kure Atoll, Midway Atoll and Pearl and Hermes Reef are adjacent to each other at the

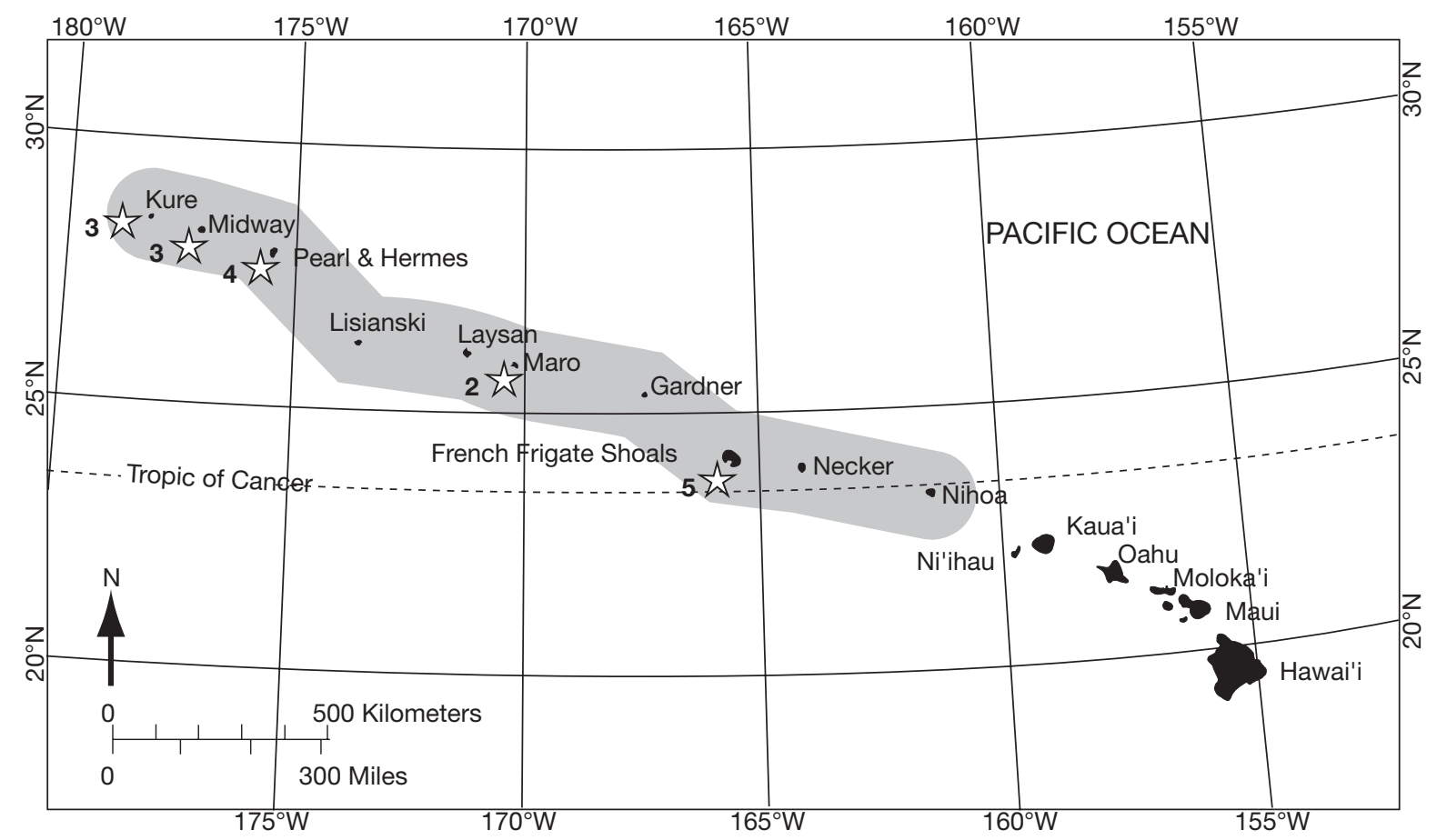

Fig. 1. Hawaiian Archipelago showing locations ( $\downarrow \xi)$ and numbers (bold) of VR2 receiver deployments in the Northwestern Hawaiian Islands Marine National Monument (shaded area) 
Table 1. Description of study site atolls. Adapted from DeMartini \& Friedlander (2004)

\begin{tabular}{|c|c|c|c|c|}
\hline Reef & Reef type(s) & $\begin{array}{l}\text { Reef area }\left(\mathrm{km}^{2}\right) \\
<20 \mathrm{~m} \text { depth }\end{array}$ & $\begin{array}{c}\text { Length of } \\
\text { longest axis }(\mathrm{km})\end{array}$ & $\begin{array}{l}\text { Distance to } \\
\text { nearest VR2 arrayed } \\
\text { reef }(\mathrm{km})\end{array}$ \\
\hline Kure Atoll (KUR) & Atoll & 68 & 10 & 100 (MID) \\
\hline Midway Atoll (MID) & Atoll & 80 & 11 & 100 (KUR) \\
\hline Pearl and Hermes Reef (PHR) & Atoll & 403 & 32 & 150 (MID) \\
\hline Maro Reef (MAR) & Open atoll, reticulated reef & 188 & 28 & 478 (FFS) \\
\hline French Frigate Shoals (FFS) & Part drowned atoll, pinnacle & 469 & 36 & 478 (MAR) \\
\hline
\end{tabular}

northwestern end of the archipelago. Kure is separated from Midway by $100 \mathrm{~km}$ and Midway is separated from Pearl and Hermes Reef by $150 \mathrm{~km}$. The openocean distance between atolls equipped with our acoustic receivers ranged from 100 to $478 \mathrm{~km}$ (Table 1).

Acoustic monitoring system. We used the Vemco ${ }^{\mathrm{TM}}$ VR2 acoustic monitoring system to track movements of giant trevally in the NWHI-MNM. This system consists of small (340 mm long $\times 60 \mathrm{~mm}$ diameter, weight in water $300 \mathrm{~g})$, self-contained, single channel $(69 \mathrm{kHz})$ underwater receivers that listen continually for the presence of pulse-coded acoustic transmitters. We used Vemco V16-6H transmitters (length: $94 \mathrm{~mm}$; diameter: $16 \mathrm{~mm}$; weight in water: $14 \mathrm{~g}$ ) with a battery life of approximately $732 \mathrm{~d}$ and detection range of up to $1000 \mathrm{~m}$. These transmitters periodically emit a 'pulse train' of closely spaced $69 \mathrm{kHz}$ 'pings', that uniquely identify each transmitter. These pulse trains are typically $3.1 \mathrm{~s}$ in length (R04K code map) and our transmitters were silent for 10 to $35 \mathrm{~s}$ between each pulse train. Each successfully decoded pulse train is recorded as a single detection by a VR2 receiver, and is stored in the receiver memory as the unique transmitter number, date and time of detection. If multiple transmitters are simultaneously present within the detection range of a receiver, the pulse trains periodically overlap. In most cases this will simply prevent the receiver from successfully decoding the overlapping transmissions, but on rare occasions ( $\leq 1$ per $24 \mathrm{~h}$ per identification code) these collisions result in single spurious detections being recorded by the receiver. We filtered our data to remove potentially spurious detections (see 'Data analysis' below).

Capture and tagging methods. In May and September 2005, we captured 28 giant trevally in the general vicinity of our acoustic receiver stations at 4 atolls (MID, PHR, MAR, FFS) by trolling (towing an artificial lure) and handlining (using a single baited hook) from a small skiff (Table 2). We brought captured giant trevally alongside the skiff, where we tail-roped and inverted them to initiate tonic immobility. Giant trevally remained docile in this position while we surgically implanted transmitters into the body cavities of each fish through a small incision in the abdominal wall (Meyer \& Honebrink 2005). Following transmitter insertion we closed the incision with interrupted sutures, removed the hook and released the fish. The entire handling process took less than $10 \mathrm{~min}$ and all giant trevally swam away vigorously on release. Prior captive experiments using a similar surgical implantation protocol on closely related bluefin trevally Caranx melampygus resulted in 100\% survival (Meyer \& Honebrink 2005).

Receiver deployment. In May 2005, simultaneous with our transmitter deployments, we deployed 17 underwater receivers among 5 atolls (FFS, MAR, PHR, MID, KUR) (Fig. 1, Table 3). Our strategy was to span each atoll with 2 to 5 receivers, so that both inter-atoll and intra-atoll movements could be detected (e.g. Fig. 2). We placed 10 receivers at locations outside atoll barrier reefs and 7 at locations inside atoll lagoons. Depth at receiver sites ranged from 2 to $26 \mathrm{~m}$, and included most major atoll habitat types: lagoon sand flats, Acropora sp. reefs, high-energy spur and groove formations, flat pavement reef, and passes through atoll barrier reefs (Table 3). We created temporary receiver moorings at each site consisting of screw-in ground anchors in areas of soft sediment, and chain around inert substrate in hard bottom areas. The receivers were anchored to the moorings and suspended 2 to $4 \mathrm{~m}$ above the ocean floor. The receivers identified and recorded the presence of any acoustic transmitters within a range of up to $1000 \mathrm{~m}$. In September 2005 we retrieved the receivers at all 5 atolls, downloaded the stored data (transmitter codes detected, dates and times of detection) and redeployed them at their original locations. In May 2006, we again retrieved, downloaded and redeployed the receivers stationed at FFS.

Data analysis. We first filtered our data to remove any potentially spurious transmitter detections. We defined spurious detections as any single transmitter code detection occurring alone within a $24 \mathrm{~h}$ period. All other detections were treated as genuine, with every successfully decoded pulse train treated as a single detection. We quantified the scale of giant trevally movements by measuring the minimum distances traveled between points of capture and subsequent detec- 
Table 2. Caranx ignobilis. Summary of acoustic monitoring data for 28 transmitter-equipped giant trevally captured at 4 NWHI atolls. Capture locations characterized as on, or outside atoll barrier reefs (BR) or inside atoll lagoons (L)

\begin{tabular}{|c|c|c|c|c|c|c|c|c|}
\hline $\begin{array}{l}\text { Capture } \\
\text { location }\end{array}$ & $\begin{array}{c}\text { Trans- } \\
\text { mitter } \\
\text { code }\end{array}$ & $\begin{array}{c}\text { Fork } \\
\text { length } \\
(\mathrm{cm})\end{array}$ & $\begin{array}{c}\text { Date } \\
\text { deployed }\end{array}$ & $\begin{array}{c}\text { Date } \\
\text { first } \\
\text { detected }\end{array}$ & $\begin{array}{c}\text { Date } \\
\text { last } \\
\text { detected }\end{array}$ & $\begin{array}{c}\text { Overall } \\
\text { detection } \\
\text { period (d) }\end{array}$ & $\begin{array}{c}\text { Total no. } \\
\text { of days } \\
\text { detected }\end{array}$ & $\begin{array}{c}\text { Total } \\
\text { detections }\end{array}$ \\
\hline \multicolumn{9}{|l|}{ Midway Atoll } \\
\hline Frigate Point (BR) & 550 & 100 & 29 May 05 & 31 May 05 & 27 Sep 05 & 119 & 80 & 1633 \\
\hline Small Boat Basin (L) & 558 & 120 & 29 May 05 & 24 Jun 05 & 2 Jul 05 & 8 & 2 & 33 \\
\hline Cargo Pier (L) & 570 & 116 & 29 May 05 & $23 \mathrm{Jul} 05$ & 26 Aug 05 & 34 & 2 & 20 \\
\hline \multicolumn{9}{|l|}{ Pearl and Hermes Reef } \\
\hline Main Channel (BR) & 511 & 117 & 25 May 05 & 29 May 05 & 23 Sep 05 & 117 & 73 & 568 \\
\hline NW Barrier Reef (BR) & 512 & 108 & 27 May 05 & 1 Jun 05 & 22 Sep 05 & 113 & 18 & 84 \\
\hline NW Barrier Reef (BR) & 514 & 114 & 27 May 05 & 9 Aug 05 & 25 Sep 05 & 47 & 5 & 23 \\
\hline Main Channel (BR) & 520 & 119 & 24 May 05 & 24 May 05 & 23 Sep 05 & 122 & 79 & 1239 \\
\hline Main Channel (BR) & 521 & 92 & 24 May 05 & 26 May 05 & 23 Sep 05 & 120 & 143 & 2081 \\
\hline NW Barrier Reef (BR) & 564 & 108 & 27 May 05 & 15 Jul 05 & 23 Sep 05 & 70 & 6 & 27 \\
\hline Main Channel (BR) & 567 & 118 & 25 May 05 & 25 May 05 & 24 Sep 05 & 122 & 75 & 782 \\
\hline \multicolumn{9}{|l|}{ Maro Reef } \\
\hline North Tip (BR) & 503 & 118 & 21 May 05 & Not Detected & - & - & - & - \\
\hline North Tip (BR) & 506 & 112 & 21 May 05 & 21 May 05 & 20 Sep 05 & 122 & 27 & 497 \\
\hline North Tip (BR) & 507 & 115 & 21 May 05 & Not Detected & - & - & - & - \\
\hline North Tip (BR) & 508 & 130 & 21 May 05 & Not Detected & - & - & - & - \\
\hline \multicolumn{9}{|l|}{ French Frigate Shoals } \\
\hline Shark Island (BR) & 524 & 111 & 18 May 05 & 21 May 06 & 21 May 06 & 1 & 2 & 34 \\
\hline South of Disappearing Island (BR) & 525 & 108 & 16 May 05 & 26 May 05 & 16 May 06 & 355 & 83 & 753 \\
\hline Rapture Reef (BR) & 527 & 93 & 17 May 05 & 17 May 05 & 22 May 06 & 370 & 222 & 30959 \\
\hline Shark Island (BR) & 528 & 99 & 18 May 05 & 26 May 05 & 18 May 06 & 357 & 14 & 151 \\
\hline Rapture Reef (BR) & 529 & 91 & 17 May 05 & 17 May 05 & 18 May 06 & 367 & 33 & 1949 \\
\hline North of Tern Island (BR) & 530 & 118 & 18 May 05 & Not Detected & $1-$ & - & - & - \\
\hline La Perouse (L) & 537 & 89 & 18 Sept 05 & 18 Sept 05 & 26 May 06 & 250 & 136 & 45435 \\
\hline La Perouse (L) & 551 & 99 & 18 Sept 05 & 18 Sept 05 & 22 May 2006 & 246 & 136 & 17704 \\
\hline West of Tern Island (BR) & 560 & 111 & 19 May 05 & 3 Jun 05 & 10 May 06 & 341 & 46 & 222 \\
\hline La Perouse (L) & 617 & 91 & 18 Sept 05 & 18 Sept 05 & 24 May 06 & 248 & 170 & 9056 \\
\hline La Perouse (L) & 619 & 100 & 18 Sept 05 & 18 Sept 05 & 21 Apr 06 & 215 & 61 & 13402 \\
\hline La Perouse (L) & 621 & 103 & 18 Sept 05 & 18 Sept 05 & 26 May 06 & 250 & 167 & 12590 \\
\hline West of Tern Island (BR) & 622 & 106 & 19 May 05 & $3 \mathrm{Jul} 05$ & 20 May 06 & 321 & 10 & 158 \\
\hline West of Tern Island (BR) & 623 & 107 & 19 May 05 & 24 May 05 & 16 May 06 & 357 & 17 & 120 \\
\hline
\end{tabular}

tion locations, and by calculating the frequency with which giant trevally moved back and forth between receivers spaced at different distances apart. We further investigated whether giant trevally occupied core areas within each atoll by using a multiple regression analysis to examine how much of the variation in the total number of detections recorded by each receiver was accounted for by the distance between tagging and receiver sites, and how much was explained by differences among individual trevally. This analysis was based on the assumption that fish which utilize well-defined core areas are more likely to be captured within these core areas than elsewhere, and thus likely to be detected more frequently by receivers stationed close to capture locations than by those stationed far away. We pooled data from all giant trevally for this analysis, including single values for fish that were only detected by 1 receiver and multiple values for fish that were detected by $>1$ receiver.

We used time series analysis (Fast Fourier Transformation with Hamming window smoothing) to identify cyclical patterns in giant trevally behavior at French Frigate shoals. A Fast Fourier Transformation (FFT) breaks down time-series data into component frequencies, and then searches the data for any sinusoidal patterns. The frequencies of dominant patterns are identifiable as peaks within a frequency power spectrum (see Chatfield 1996). We applied FFTs to data from each receiver at FFS after firstly pooling the detections of all giant trevally into hourly bins throughout the 12 mo monitoring period (May 2005 to May 2006), and then totaling the number of fish detected at each receiver into daily bins throughout the 12 mo monitoring period.

We further investigated possible temporal diel and lunar patterns in giant trevally detections by binning detection data for each giant trevally into diel (day/ night) and lunar (new moon/full moon) phases, and then comparing mean detections in each phase bin. We used sunrise and sunset times to define the boundaries of the diel bins. Based on visual evidence of apparent lunar rhythmicity evident in the raw data, we 
Table 3. Acoustic receiver locations and numbers of giant trevally detected at 5 NWHI atolls

\begin{tabular}{|c|c|c|c|c|c|}
\hline Location & $\begin{array}{l}\text { Latitude } \\
\qquad\left({ }^{\circ} \mathrm{N}\right)\end{array}$ & $\begin{array}{c}\text { Longitude } \\
\left({ }^{\circ} \mathrm{W}\right)\end{array}$ & Depth (m) & Habitat description & $\begin{array}{c}\text { Number of } \\
\text { trevally } \\
\text { detected }\end{array}$ \\
\hline \multicolumn{6}{|l|}{ Kure Atoll } \\
\hline North Flats & 28.452 & 178.315 & 4 & Shallow lagoonal sand flats & 0 \\
\hline West Channel & 28.404 & 178.375 & 12 & Barrier reef pass/spur \& groove & 0 \\
\hline West Channel & 28.389 & 178.360 & 14 & Barrier reef pass/spur \& groove & 0 \\
\hline \multicolumn{6}{|l|}{ Midway Atoll } \\
\hline North Flats & 28.277 & 177.372 & 2 & Shallow lagoonal sand flats & 1 \\
\hline Fish Hole & 28.197 & 177.363 & 12 & Spur \& groove outside barrier reef & 3 \\
\hline Frigate Point & 28.191 & 177.395 & 9 & Reef wall outside barrier reef & 3 \\
\hline \multicolumn{6}{|l|}{ Pearl and Hermes Reef } \\
\hline North West Side & 27.910 & 175.909 & 15 & High energy spur \& groove, outside barrier reef & 5 \\
\hline Main Channel & 27.791 & 175.863 & 11 & Barrier reef pass/flat pavement reef & 4 \\
\hline South East Channel & 27.787 & 175.836 & 9 & Barrier reef pass/flat pavement reef & 4 \\
\hline South West Corner & 27.753 & 175.948 & 15 & Flat pavement reef outside barrier reef & 5 \\
\hline \multicolumn{6}{|l|}{ Maro Reef } \\
\hline North Tip & 25.458 & 170.671 & 17 & Sand channel in spur \& groove & 1 \\
\hline South End & 25.378 & 170.567 & 6 & Reef wall of 3 to $20 \mathrm{~m}$ dropoff & 0 \\
\hline \multicolumn{6}{|l|}{ French Frigate Shoals } \\
\hline Trig Island & 23.869 & 166.242 & 3 & Shallow lagoonal sand flats & 0 \\
\hline Tern Island & 23.867 & 166.288 & 5 & Shallow lagoonal sand flats & 1 \\
\hline East Island & 23.787 & 166.207 & 3 & Shallow lagoonal sand flats & 3 \\
\hline La Perouse Pinnacle & 23.769 & 166.262 & 9 & Spur \& groove, adjacent to basalt pinnacle & 6 \\
\hline Rapture Reef & 23.635 & 166.186 & 26 & High coral cover Acropora sp. reef & 12 \\
\hline
\end{tabular}
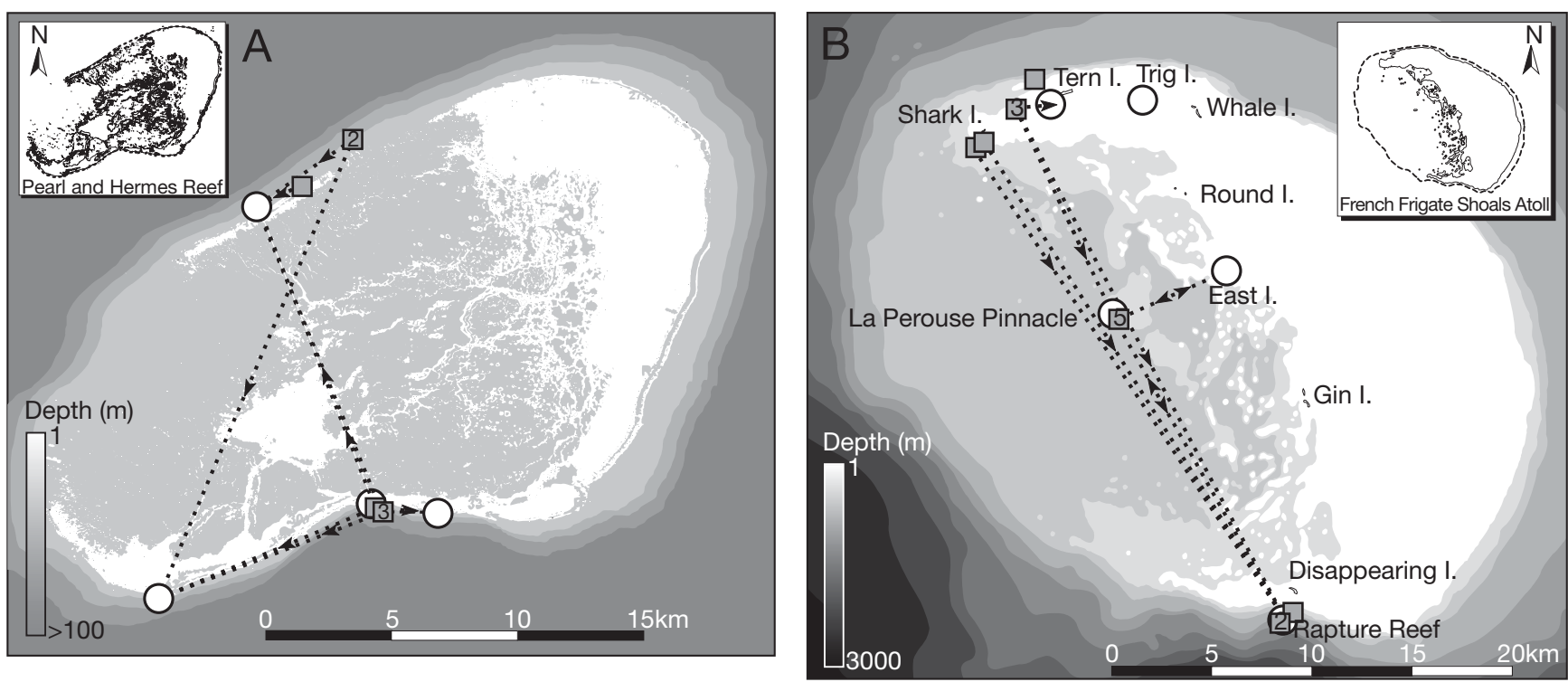

Fig. 2. Caranx ignobilis. Trans-atoll movements of giant trevally at (A) Pearl and Hermes Reef and (B) French Frigate Shoals. Circles indicate locations of VR2 receivers, shaded squares indicate giant trevally capture sites; numbers within square symbols indicate sites where multiple individuals were tagged and released. Lines with arrows indicate most direct route between giant trevally release and detection locations

defined the new moon phase as being from the day of the new moon until the last day of the first quarter, and the full moon phase as being from the day of the full moon until the last day of the third quarter. We used individual transmitter detections to assess diel patterns, and the number of days on which each fish was detected to test for lunar patterns. We first tested the raw data to determine whether they met the assumptions required for parametric testing, and then compared mean detections using temporal phase ('diel' or 'lunar') as independent factors. We used a 1-tailed $t$-test (assuming unequal variance) to evaluate the hypothesis that the mean number of giant trevally detections was significantly higher during the day than 
at night (Sokal \& Rohlf 1995). We used an analysis of variance (ANOVA) to compare the mean number of days on which giant trevally were detected during the new and full moon phases of the lunar cycle (Sokal \& Rohlf 1995).

\section{RESULTS}

Between May and September 2005, 11 (65\%) of our 17 receivers detected $24(86 \%)$ of 28 transmitterequipped giant trevally over periods spanning from 1 to 370 d (median: 168.5 d) (Table 2). The total number of days on which each fish was detected ranged from 2 to 222 (median: 53.5 d) (Table 2). Eight of the receivers that detected giant trevally were located outside atoll barrier reefs and the remaining 3 were at lagoonal sites. Each of these receivers detected between 1 and 12 (median: 4) giant trevally and the total number of transmitter detections recorded per fish ranged from 20 to 45435 (median: 660 detections) (Tables 2 \& 3).

\section{Scale of movements}

We detected no inter-atoll movements by giant trevally during our 5 and 12 mo monitoring periods but found that the fish did range widely within the 3 atolls (FFS, PHR, MID) where they were tagged. For example, we detected 16 individuals at distances of between 10 and $29 \mathrm{~km}$ away from their capture sites, and 12 giant trevally moved distances of 10 to $19 \mathrm{~km}$ between receiver locations (Fig. 2). The majority of larger scale and atoll-wide (10 to $29 \mathrm{~km}$ ) movements were occasional, relatively brief (median: $6.8 \mathrm{~d}$ ) excursions away from the core areas of activity that were persistently utilized for most of the monitoring period. Thus, although we detected a total of 231 movements between receivers by 14 giant trevally, 168 (73\%) of these were movements back and forth over distances $<5 \mathrm{~km}$. The use of core areas by giant trevally was also indicated by a significant correlation between the proximity of fishes capture location to a receiver and the number of detections of that fish recorded on the receiver (Pearson $r=-0.6, p<0.01$ ). Giant trevally were detected significantly more frequently by receivers close to their capture locations than by those stationed further away $(t=$ -4.95, p < 0.001), whereas there was no significant effect of individual tre- vally on the total number of detections $(t=0.38, \mathrm{p}=$ 0.71). However, the distance between receiver and fish capture locations accounted for only $35 \%$ of the total variance in number of detections (Fig. 3), possibly because of seasonal convergence by giant trevally from widely spaced locations at French Frigate Shoals on a single area (Rapture Reef) at the southern end of the atoll (Figs. 2, 4 \& 5).

\section{Temporal pattern of movements}

We observed 3 distinct temporal patterns (diel, lunar, seasonal) of giant trevally movements in the NWHIMNM (Figs. 4 to 7). FFT analyses of data from French Frigate Shoals atoll revealed a dominant $24 \mathrm{~h}$ peak in number of detections at the La Perouse and Rapture Reef receivers, indicating a strong diel cycle of behavior (Fig 6A,B). Giant trevally at all atolls showed significant diel variation in habitat use $(t=-2.34, \mathrm{df}=23, \mathrm{p}<$ $0.05)$, with receivers detecting most individuals more often during daytime (mean detections: $5569 \pm 2271 \mathrm{SE}$ ) than at night (mean detections: $244 \pm 68 \mathrm{SE}$ ). At French Frigate Shoals we also observed a distinct lunar pattern in giant trevally movements that was not evident at the other atolls. FFT analyses indicated a strong monthly signal in the number of fish visiting Rapture Reef at the southern end of French Frigate Shoals atoll (Fig. 6C). We found significant differences in the mean number of days that giant trevally visited Rapture Reef (Figs. 4 \& 5) during different phases of the lunar cycle $(F=11.67, \mathrm{df}=17, \mathrm{p}=0.003)$. Giant trevally captured elsewhere at French Frigate Shoals visited Rapture Reef primarily during the full moon and third quarter phases of the lunar cycle (Figs. 4 \& 5). This lunar pattern was seasonal; it did not occur during the winter months (October to January). For example, the 5 giant trevally captured at La Perouse Pinnacle were resident

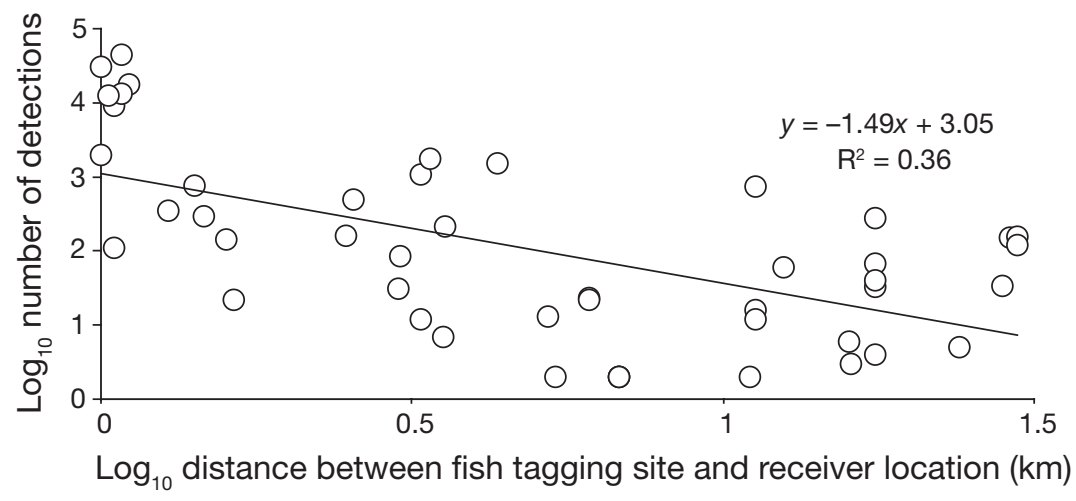

Fig. 3. Caranx ignobilis. Regression analysis of $\log _{10}$ distance between giant trevally capture site and receiver location versus $\log _{10}$ number of detections. Regression analysis includes multiple distance measurements from 14 giant trevally that were detected at $>1$ receiver location 


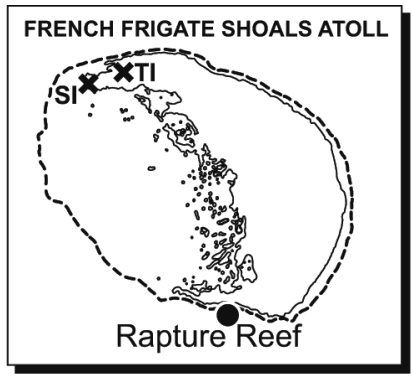

Fig. 4. Caranx ignobilis. Diel, lunar and seasonal detection patterns of 7 giant trevally observed at Rapture Reef (FFS) from May 2005 to May 2006. These were initially captured at Rapture Reef (RR), Shark Island (SI) and Tern Island (TI) in May 2005. Note horizontal stripes of shading show nighttime periods and vertical lines show new (N, dashed) and full $(\mathrm{F}$, dotted) moons. Giant trevally detections at Rapture Reef (solid points) were concentrated during daytime (white bands) and less frequent during nighttime (gray bands)

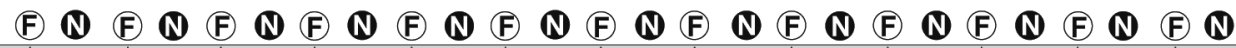
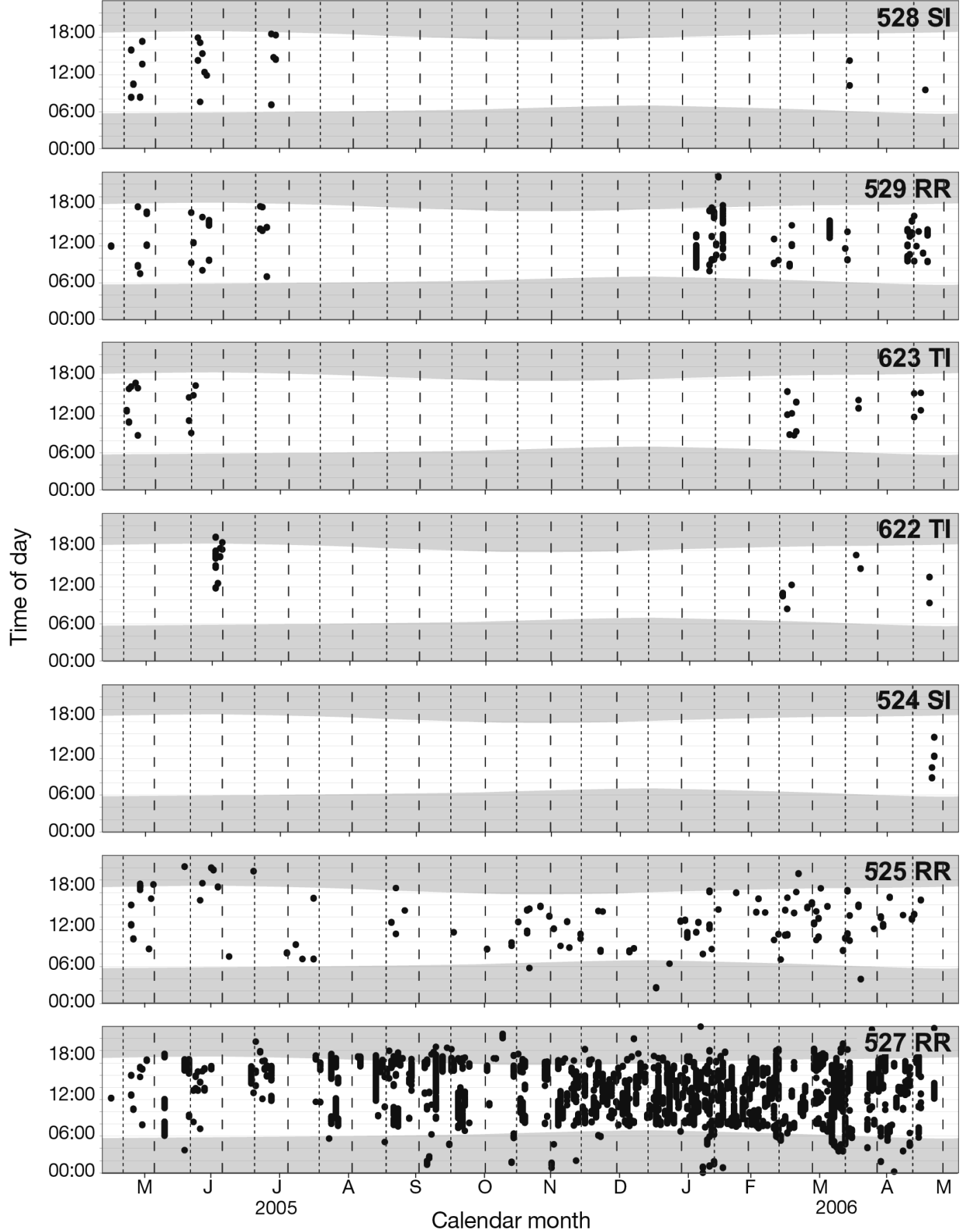


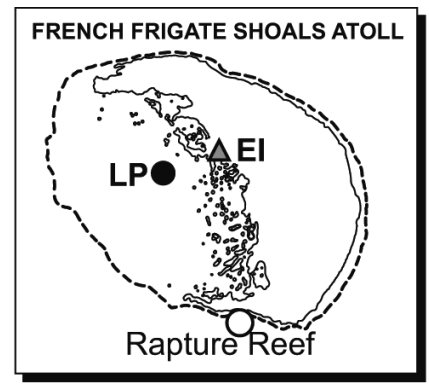

Fig. 5. Caranx ignobilis. Diel, lunar and seasonal detection patterns of 5 giant trevally captured at La Perouse Pinnacle (LP) in September 2005. Note the horizontal stripes of shading to show nighttime periods on the graphs and vertical lines to show new ( $\mathrm{N}$, dashed) and full ( $\mathrm{F}$, dotted) moons. Between September 2005 and May 2006 these fish were detected at La Perouse Pinnacle (solid points), Rapture Reef (unshaded circles) and East Island (EI) (shaded triangles)
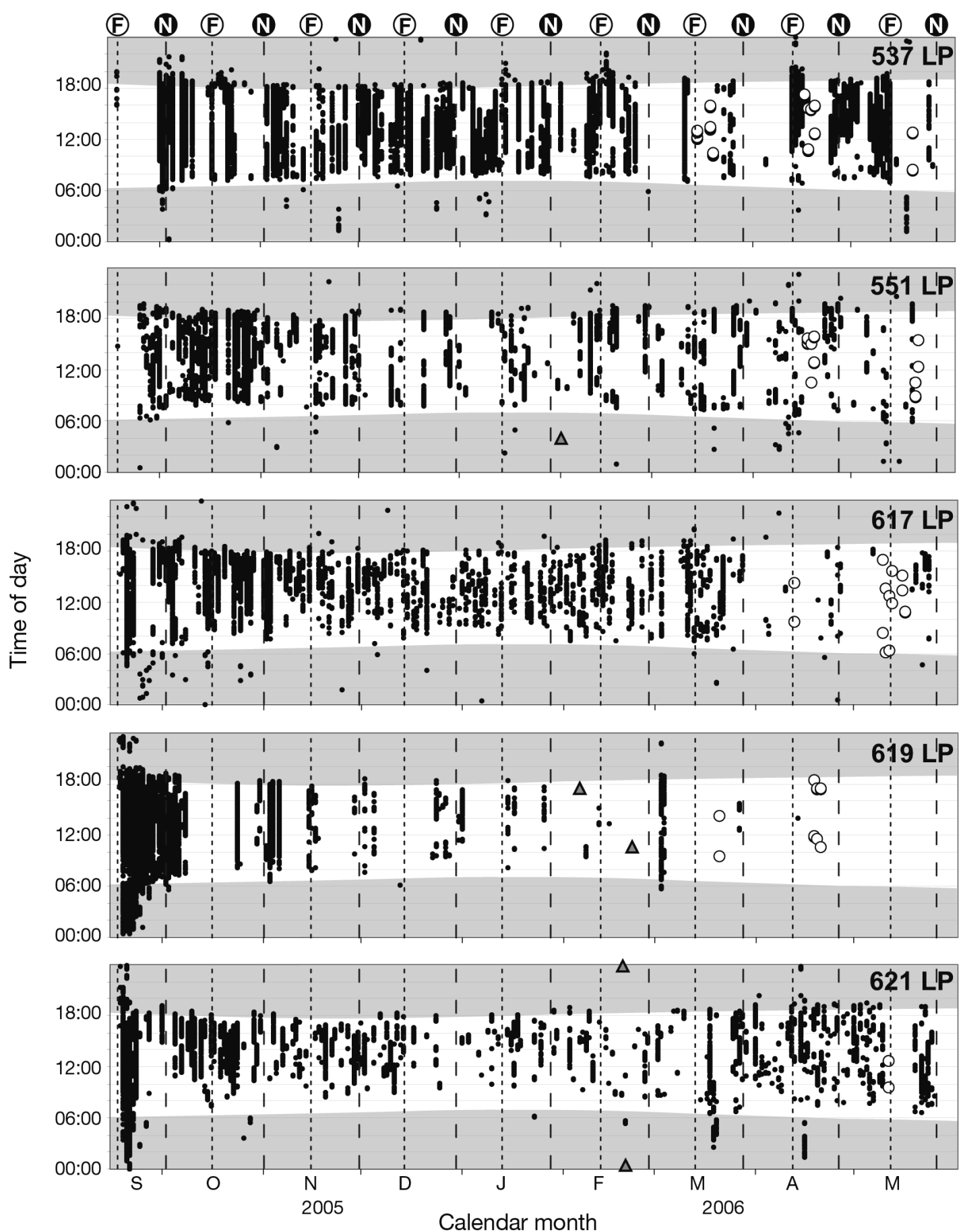

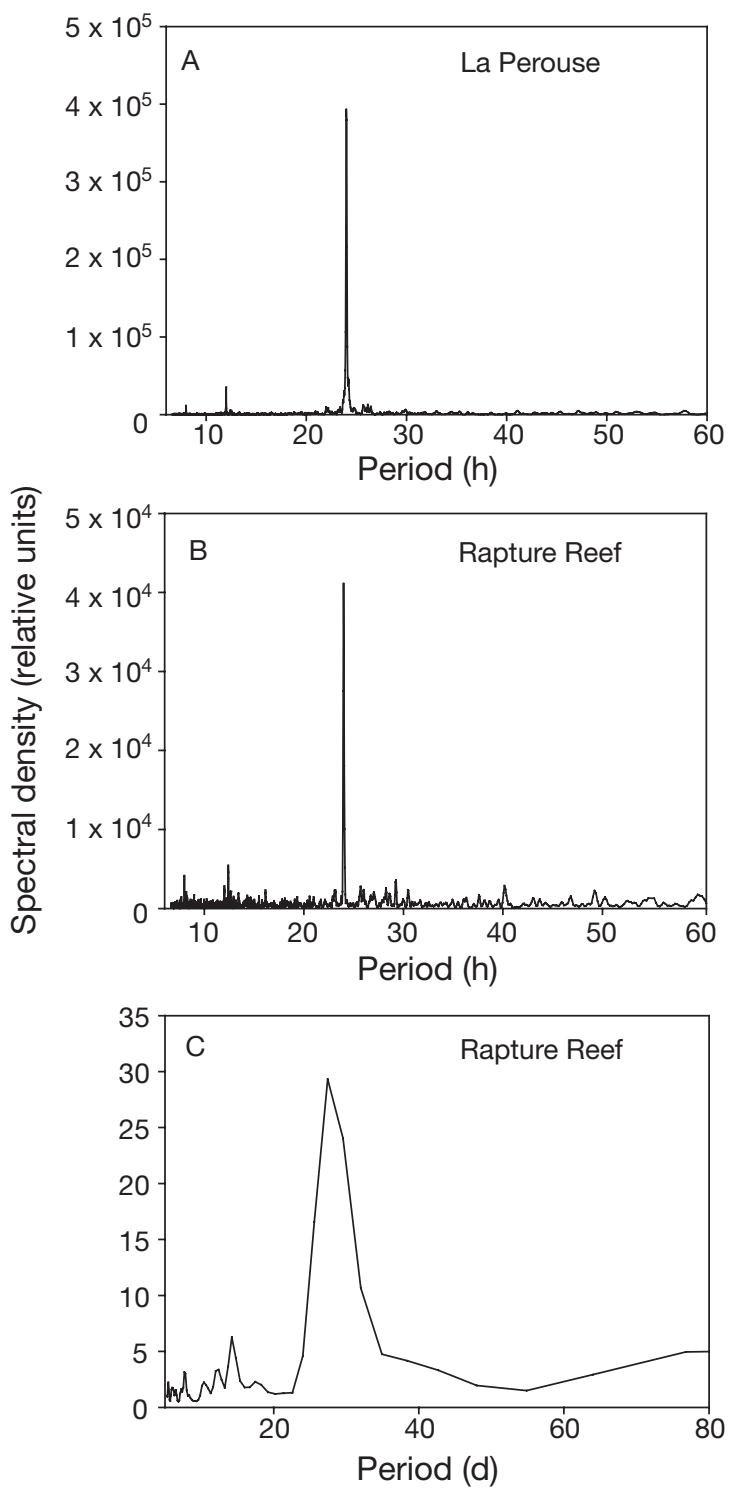

Fig. 6. Caranx ignobilis. Time-series spectral analyses of giant trevally behavior at French Frigate Shoals atoll. Fast Fourier Transformations (FFT) of number of hourly detections at (a) La Perouse and (b) Rapture Reef. (c) FFT applied to number of fish detected daily at Rapture Reef. Peaks indicate frequencies of dominant cycles in behavior patterns. Note the use of different scales on $y$-axis

there during winter and then began to travel back and forth between La Perouse Pinnacle and Rapture Reef during early spring (Fig. 5). In total, 9 of the giant trevally exhibiting lunar periodicity in visiting Rapture Reef were originally captured at locations between 17 and $29 \mathrm{~km}$ away from this site in the center and North end of FFS atoll (Figs. 2, 4 \& 5). On 23 May 2006 (9 d after the full moon), we sighted a large school of giant trevally containing both light and dark colored individuals while SCUBA diving at Rapture Reef (Fig. 8).

\section{DISCUSSION}

Movement patterns of giant trevally in the NWHIMNM were consistent with the general reef fish site attachment model, but differed in scale from that of other previously investigated coral reef fishes. Over our 5 to 12 mo monitoring period, giant trevally frequently moved back and forth over distances of up to $5 \mathrm{~km}$, and periodically ranged across entire atolls, with minimum distances of 10 to $29 \mathrm{~km}$. The regular movements of other previously-studied coral reef fishes are on a much smaller scale, ranging from a few meters up to a few kilometers (Ogden \& Buckman 1973, Holland et al. 1993, Holland et al. 1996, Zeller 1997, Righton et al. 1998, Meyer et al. 2000, Meyer 2003, Meyer \& Holland 2005, Meyer \& Honebrink 2005).

Giant trevally were frequently within detection range of our receivers by day but moved out of range at night. This bias toward daytime detections probably occurred because we captured all of our giant trevally during daytime, when they were occupying daytime habitats, and the receivers that recorded the most giant trevally detections were stationed at capture sites. Diel habitat shifts are common in a wide variety of coral reef fishes, including carangids (Holland et al. 1996, Meyer 2003, Meyer \& Honebrink 2005), and for many the crepuscular 'commute' between day and night habitats accounts for the maximum linear dimension of their daily home ranges (Holland et al. 1996, Meyer et al. 2000, Meyer 2003, Meyer \& Holland 2005, Meyer \& Honebrink 2005).

Our observations at FFS of lunar patterns in giant trevally detections during spring and summer, and the visual observation of a giant trevally school containing both light and dark colored individuals, are consistent with previous descriptions of giant trevally spawning behavior. For example, several authors have documented giant trevally spawning aggregations in similar habitats during the full moon in other areas of the Pacific, and noted that the timing and locations of these aggregations are well known to Pacific Islanders (Williams 1965, Bagnis et al. 1972, von Westerhagen 1974, Johannes 1978, 1981). Both Talbot \& Williams (1956) and von Westerhagen (1974) observed sexual color differences in giant trevally in spawning aggregations, with males being conspicuously darker than females. Sudekum et al. (1991) examined the gonads of giant trevally captured in the NWHI and determined that peak spawning occurs during the summer months. We also saw evidence that giant trevally from across FFS atoll converge on a preferred spawning location (Rapture Reef) during spring and summer. For example, 9 individuals exhibiting a seasonal lunar detection pattern at Rapture Reef were originally captured at locations between 17 and $29 \mathrm{~km}$ north of this site. Of 


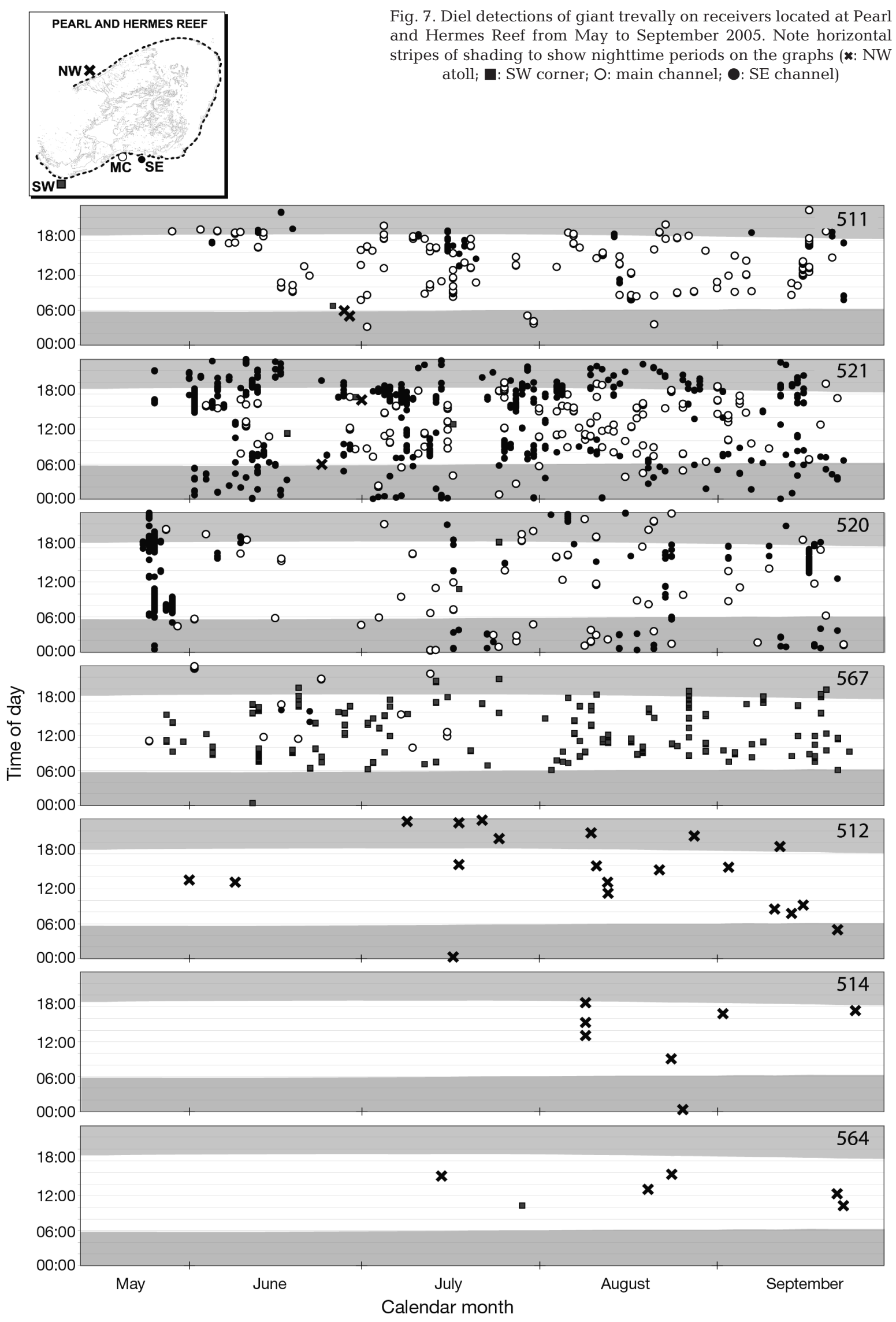



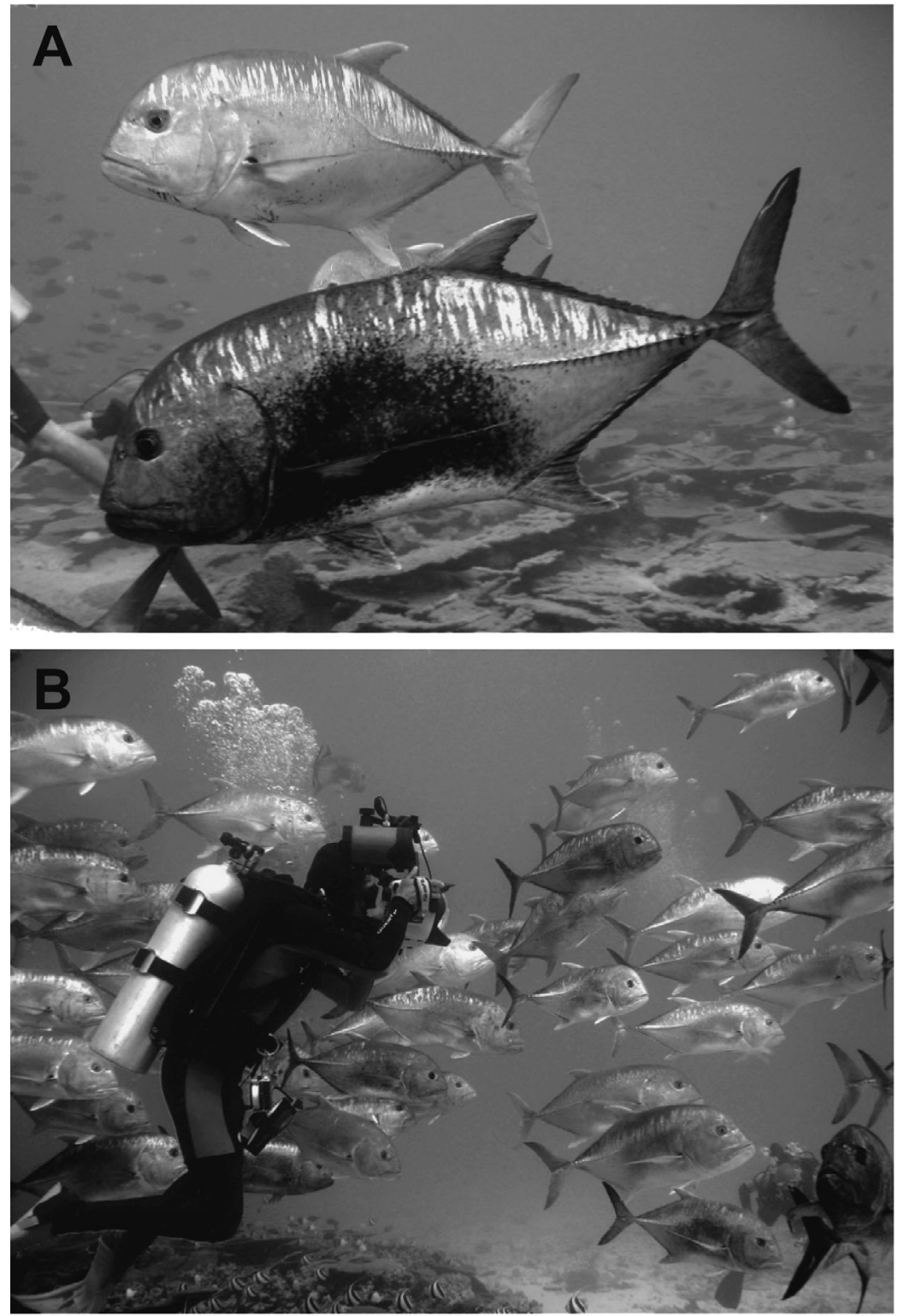

Fig. 8. Caranx ignobilis. (A) Color dimorphism in giant trevally from school at Rapture Reef. (B) Giant trevally school at Rapture Reef (FFS Atoll), 23 May 2006 Photographs reproduced with permission from Jill Zamzow

these 9 , the patterns of 5 giant trevally captured at La Perouse Pinnacle clearly show the seasonal nature of spawning habitat use; these fish were resident at La Perouse Pinnacle during winter and then began to travel back and forth between La Perouse and Rapture Reef during early spring. The discovery of this behavior emphasizes the value of acoustic telemetry for identifying group spawning sites or other critical habitats.

Although we saw no evidence of inter-atoll movements, we cannot rule out the possibility that these movements occurred. For example, we observed gaps in giant trevally detections ranging from hours to weeks or months, and we do not know where these individuals went when not being detected by our receivers. It is possible that giant trevally visited other non-monitored atolls during some of the periods of absence. Four of our tagged giant trevally were never detected by our receivers, and these fish may also have moved to other atolls. However, 3 of these 'missing' fish were originally captured and released at Maro Reef, which has an extensive, reticulated reef structure and we placed only 2 receivers at this site. Thus, these fish may have been continually present at Maro Reef, but never ventured into receiver detection range.

The wide-ranging behavior of giant trevally has clear management implications; either MPAs must be large enough to contain giant trevally movements or alternative management strategies must be used to prevent overexploitation of these coral reef top predators. The elimination of fishing from entire atolls in the NWHI-MNM guarantees complete protection of wideranging top predators such as giant trevally and enables the persistence of a predator dominated fish fauna in this region of the Hawaiian Archipelago. However, few MPAs are as large and remote as the NWHI-MNM (see Halpern 2003). For example, existing MPAs in the populated Main Hawaiian Islands (MHI) range in size from 0.14 to $1.2 \mathrm{~km}^{2}$ ( 0.8 to $3.3 \mathrm{~km}$ of linear coastline). A previous MHI study found that juvenile giant trevally regularly venture outside the boundaries of one of these small MPAs (Wetherbee et al. 2004). Our recent data and those of a previous smallscale study (Lowe et al. 2006) suggest that MPAs of this size are also too small to effectively protect adult giant trevally. This may explain why adult giant trevally are very rarely seen in these small MPAs, whereas large individuals of the closely related, but less wide-ranging, bluefin trevally Caranx melampygus are relatively common at these sites (Holland et al. 1996, Meyer 2003, Wetherbee et al. 2004, Meyer \& Honebrink 2005).

So how large would MPAs need to be in order to protect adult giant trevally? We found that although giant trevally undertook periodic atoll-wide excursions, most of their detected movements were restricted to 
smaller core areas within each atoll. Although our limited receiver coverage permits only crude linear estimates of the size of these core areas, we found that the majority $(73 \%)$ of movements between receivers occurred over linear distances $<5 \mathrm{~km}$. However, there are 3 important caveats to our conservative size estimate of adult giant trevally core activity areas: (1) our preliminary estimate is derived from only 5 to 12 mo of monitoring; (2) our data suggest that giant trevally undertake larger-scale seasonal movements which may be linked to spawning activity (Williams 1965, Bagnis et al. 1972, von Westerhagen 1974, Johannes 1978); and (3) we do not know how far giant trevally roamed beyond detection range of our receivers.

Seasonal spawning migrations present a particular management challenge because targeted fishes may leave core activity areas inside small MPAs and travel long distances to reach preferred spawning sites (Bolden 2000). Fish may also aggregate in large groups and become more vulnerable to capture at these sites (von Westerhagen 1974, Johannes 1981, Sala et al. 2002, 2003, Sadovy \& Domeier 2005). However, if spawning sites can be identified then small MPAs can be used specifically to protect fish aggregating at these locations and times of year (Sala et al. 2002, 2003, Sadovy \& Domeier 2005). These small MPAs could have significant impact in preserving giant trevally spawning biomass.

Resource managers in populated areas need management solutions that balance conservation with sustainable exploitation. Although MPAs are an attractive management tool, their establishment is strongly contested by stakeholders who must yield access rights to enable MPA creation, and this social resistance limits the size and number of MPAs established in populated areas (Wolfenden et al. 1994, Cocklin et al. 1998, Agardy et al. 2003). Our data show that giant trevally are wider ranging than most other coral reef fishes for which empirical movement data are currently available and consequently this species requires larger MPAs than most of those that currently exist. The most straightforward solution to conserving wide-ranging fishes is to create very large MPAs (e.g. the NWHIMNM) that will easily contain their movements but this is clearly not feasible in populated areas. We suggest that an effective alternative management strategy may be to use networks of relatively small ( $>5 \mathrm{~km}$ in length) MPAs to protect core activity areas and spawning sites for giant trevally, and conventional measures such as minimum size or 'slot' limits to further safeguard spawning stocks. Seasonal closures could also be used to protect giant trevally during the spawning season.

In order to refine our core area size estimate for giant trevally we need to know which areas are visited at night and how far these sites are from the daytime habitat. We aim to address these questions in future studies by using active tracking to obtain more complete, higher resolution information on the short-term movements of giant trevally, and by increasing the number of receivers deployed around individual atolls to obtain a more complete long-term picture of giant trevally movements (Holland et al. 1996, Meyer et al. 2000, Meyer 2003, Meyer \& Holland 2005). Additional studies will be necessary to determine whether networks of relatively small MPAs will provide effective long-term protection for a wide range of coral reef top predators.

Acknowledgements. We thank the crew of the NOAA ship 'Hi'ialakai', especially coxswains M. Gordon, G. Maurizio and J. Kehn for scientific mission support. We thank R. Kosaki, B. Bowen, M. Craig, J. Eble, H. Walsh and D. Nichols for their assistance in the field. This study was funded by an award to Hawaii Institute of Marine Biology from the National Marine Sanctuary Program (MOA 2005-008/6882). This work was carried out in accordance with the animal use protocols of the University of Hawaii (protocol \#05-053) and conducted under NOAA-NWHICRER permit \# 2005-010, U.S. Fish \& Wildlife Special Use Permits \# 12521-05020 and \# 12521-06021 and State of Hawaii Department of Land and Natural Resources permit \# DLNR.NWHI06R003.

\section{LITERATURE CITED}

Agardy T, Bridgewater P, Crosby MP, Day J and 7 others (2003) Dangerous targets? Unresolved issues and ideological clashes around marine protected areas. Aquat Conserv Mar Freshw Ecol 13:353-367

Bagnis R, Mazellier P, Bennett J, Christian E (1972) Fishes of Polynesia. Les Editions du Pacifique, Tahiti

Berry FH, Smith-Vaniz WF, Moberly JB (1981) Identification of trevallys or crevalles (genus Caranx) of the Indian and Pacific Oceans. International Game Fish Association, Fort Lauderdale, FL

Bolden S (2000) Long-distance movement of a Nassau grouper (Epinephelus striatus) to a spawning aggregation in the central Bahamas. Fish Bull 98:642-645

Chatfield C (1996) The analysis of time series: an introduction, 5th edn. Chapman \& Hall, Boca Raton, FL

Cocklin C, Craw M, McAuley I (1998) Marine reserves in New Zealand: use rights, public attitudes and social impacts. Coast Manage 26:213-231

DeMartini EE, Friedlander AM (2004) Spatial patterns of endemism in shallow-water reef fish populations of the Northwestern Hawaiian Islands. Mar Ecol Prog Ser 271: 281-296

DeMartini EE, Friedlander AM, Holzwarth SR (2005) Size at sex change in protogynous labroids, prey body size distributions, and apex predator densities at NW Hawaiian atolls. Mar Ecol Prog Ser 297:259-271

Friedlander AM, DeMartini EE (2002) Contrasts in density, size, and biomass of reef fishes between the northwestern and the main Hawaiian islands: the effects of fishing down apex predators. Mar Ecol Prog Ser 230:253-264

Gerber LR, Heppell SS, Ballantyne F, Sala E (2005) The role of dispersal and demography in determining the efficacy of marine reserves. Can J Fish Aquat Sci 62:863-871 
Halpern BS (2003) The impact of marine reserve: do reserves work and does reserve size matter? Ecol Appl 13: S117-S137

Holland KN, Peterson JD, Lowe CG, Wetherbee BM (1993) Movements, distribution and growth rates of the white goatfish Mulloides flavolineatus in a fisheries conservation zone. Bull Mar Sci 52:982-992

Holland KN, Lowe CG, Wetherbee BM (1996) Movements and dispersal patterns of blue trevally (Caranx melampygus) in a fisheries conservation zone. Fish Res 25:279-292

Johannes RE (1978) Reproductive strategies of coastal marine fishes in the tropics. Environ Biol Fish 3:65-84

Johannes RE (1981) Words of the lagoon: fishing and marine lore in the Palau District of Micronesia. University of California Press, Berkley, CA

Kramer DL, Chapman MR (1999) Implications of fish home range size and relocation for marine reserve function. Envrion Biol Fish 55:65-79

Lowe CG, Wetherbee BM, Meyer CG (2006) Using acoustic telemetry monitoring techniques to quantify movement patterns and site fidelity of sharks and giant trevally around French Frigate Shoals and Midway Atoll. Atoll Res Bull 543:281-303

Meyer CG (2003) An empirical evaluation of the design and function of a small marine reserve (Waikiki Marine Life Conservation District). Doctoral dissertation, University of Hawaii at Manoa, Honolulu, HI

Meyer CG, Holland KN (2005) Movement patterns, home range size and habitat utilization of the bluespine unicornfish, Naso unicornis (Acanthuridae) in a Hawaiian marine reserve. Environ Biol Fish 134:602-606

Meyer CG, Honebrink R (2005) Retention of surgically implanted transmitters by bluefin trevally (Caranx melampygus). Implications for long-term movement studies. Trans Am Fish Soc 134:602-606

Meyer CG, Holland KN, Wetherbee BM, Lowe CG (2000) Movement patterns, habitat utilization, home range size and site fidelity of whitesaddle goatfish, Parupeneus porphyreus, in a marine reserve. Env Biol Fish 59:235-242

Meyer CG, Holland KN, Wetherbee BM, Lowe CG (2001) Diet, resource partitioning and gear vulnerability of Hawaiian jacks captured in fishing tournaments. Fish Res 53:105-113

Nowlis JS, Roberts CM (1999) Fisheries benefits and optimal design of marine reserves. Fish Bull 97:604-616

Ogden JC, Buckman NS (1973) Movements, foraging groups, and diurnal migrations of the striped parrotfish Scarus criosensis Bloch (Scaridae). Ecology 54:589-596

Randall JE (1996) Shore fishes of Hawaii. Natural World Press, Vida, OR

Editorial responsibility: Otto Kinne (Editor-in-Chief), Oldendorf/Luhe, Germany
Righton D, Miller M, Ormond R (1998) Correlates of territory size in the butterflyfish Chaetodon austriacus (Rueppell). J Exp Mar Biol Ecol 226:183-193

Roberts CM, Polunin NVC (1993) Marine reserves: Simple solutions to managing complex fisheries? Ambio 22: 363-368

Sadovy Y, Domeier M (2005) Are aggregation-fisheries sustainable? Reef fish fisheries as a case study. Coral Reefs 24:254-262

Sadovy Y, Kulbicki M, Labrosse P, Letourneur Y, Lokani P, Donaldson TJ (2003) The humphead wrasse, Cheilinus undulatus: synopsis of a threatened and poorly known giant coral reef fish. Rev Fish Biol Fish 13:327-364

Sala E, Aburto-Oropeza O, Paredes G, Parra I, Barrera JC, Dayton PK (2002) A general model for designing networks of marine reserves. Science 298:1991-1993

Sala E, Aburto-Oropeza O, Paredes G, Thompson G (2003) Spawning aggregations and reproductive behavior of reef fishes in the Gulf of California. Bull Mar Sci 72: 103-121

Shomura RS (1987) Hawaii's marine fishery resources: yesterday (1900) and today (1986). Admin Rep H-87-21, National Marine Fisheries Service, Honolulu Laboratory, Southeast Fisheries Science Center

Sokal RR, Rohlf FJ (1995) Biometry: the principles and practice of statistics in biological research. WH Freeman, New York

Sudekum AE, Parrish JD, Radtke RL, Ralston S (1991) Life history and ecology of large jacks in undisturbed, shallow, oceanic communities. Fish Bull 89:493-513

Talbot FH, Williams F (1956) Sexual color differences in Caranx ignobilis (Forsk.). Nature 178:934

von Westernhagen $\mathrm{H}$ (1974) Observations on the natural spawning of Alectis indicus (Ruppell) and Caranx ignobilis (Forsk.) (Carangidae). J Fish Biol 6:513-516

Wetherbee BM, Holland KN, Meyer CG, Lowe CG (2004) Use of a marine reserve in Hawaii by the giant trevally, Caranx ignobilis. Fish Res 67:253-263

Williams F (1958) Fishes of the family Carangidae in British East African waters. Ann Mag Nat Hist 13:369-430

Williams F (1965) Further notes on the biology of East African pelagic fishes of the families Carangidae and Sphyraenidae. East Afr J Agr Forest 31:141-168

Wolfenden J, Cram F, Kirkwood B (1994) Marine reserves in New Zealand: a survey of community reactions. Ocean Coast Manag 25:31-51

Zeller DC (1997) Home range and activity patterns of the coral trout Plectropomus leopardus (Serranidae). Mar Ecol Prog Ser 154:65-77

Submitted: April 24, 2006; Accepted: August 24, 2006

Proofs received from author(s): March 1, 2007 